\title{
CONDITIONAL CONSERVATISM AND VALUE RELEVANCE OF FINANCIAL REPORTING: EMPIRICAL EVIDENCE OF LISTED COMPANIES IN VIETNAM
}

\author{
NGUYEN THI THUY DUNG ${ }^{1}$, HA HOANG NHAN ${ }^{2}$, MAI THI HOANG MINH ${ }^{3}$ \\ ${ }^{I}$ Ho Chi Minh City University of Law, Business and Administration Faculty, Vietnam \\ ${ }^{2}$ Industrial University of Ho Chi Minh City, Faculty of Accounting and Auditing, Vietnam \\ ${ }^{3}$ University of Economics of Ho Chi Minh City, School of Accounting, Vietnam
}

\begin{abstract}
This study shed a light on the link between conditional conservatism and value relevance of financial reporting over the period of nine years from 2008 to 2016. Using a large sample of listed firms in Vietnam, the results of the paper indicate that conservatism is a salient feature of the Vietnamese Accounting System. We also have evidence to show that there is a linear association between conservative reporting and value relevance of earnings when moving from low-conservative firms to high-conservative firms. Moreover, no evidence was found regarding the hypothesis that level of conservatism decreasing after promulgation of Circular No. 200/2014/TT-BTC regulating guidance on corporate accounting system.
\end{abstract}

Keywords: conditional conservatism, value relevance

\section{INTRODUCTION}

Some researchers in Vietnam argued that information on financial statements which provided through the process of recording and summarizing of accounting is not relevant compared to efficient markets of nations around the world. Specifically, Vietnam is a code-law based country that is different from those in the common law regimes. Thus, the protection of shareholder rights and the requirement of information transparency is lower (Vo Van Nhi and Le Hoang Phuc, 2011). Moreover, Vietnam is also a nation where accounting principles are referred to the national accounting regimes. That is, the state plays a vital role in controlling accounting methods of measurement, evaluation, drafting and presentation of reports Therefore, the drafting and promulgation of accounting standards and implementation guidelines must be implemented by state (Vo Van Nhi and Le Hoang Phuc, 2011). In particular, the accounting regimes strongly emphasizes the method of recording, making accounting entries. Furthermore, accounting methods heavily influenced by tax regulations, such as requiring enterprises to implement the account system agree on the number and name. Additionally, Vietnamese accounting standards with less estimation and more conservative limit uncertainty factors, but this reduces the relevance of information on financial statements (Nguyen Dang Huy, 2017). As a result, prudent accounting rules combines with the nature that reflects the past economic operations of the information on the financial statements make the financial reporting users are difficult to predict the future of businesses for investment purposes. In line with this argument, some studies around the world also conclude that increased accounting conservatism is a possible reason for the decline in value relevance of financial reporting (Lev and Zarowin, 1999; Francis and Schipper, 1999; Core et al, 2003). In contrast, several researches found no relationship between accounting conservatism and the appropriate value relevance of information (Balachandran and Mohanram, 2011). This inconsistency also reflected in the fact that IASB removed the notion of prudence from the Conceptual framework for financial reporting 2010 and brought back the term in its draft 2015.

In this paper, we examine the association between conditional conservatism and value relevance of financial reporting from 2008 to 2016. The remainder of the paper is as follows. In section 2, we analyze the prior literature on accounting conservatism and value relevance, focusing on definitions, 
measurements, the link between them as well as our hypotheses tested. In section 3, we discuss research model and our research design. In section 5, we illustrate our results, and finally, in section 5 and 6 we present the concluding remark and offer some limitations and directions for further research.

\section{LITERATURE REVIEW AND HYPOTHESES DEVELOPMENT}

\subsection{Definition, measurement and the relationship between accounting conservatism value relevance}

\subsubsection{Value relevance of earnings}

Value relevance research is considered as a fruitful research that attracts the attention of scholars around the world. Francis and Schipper (1999) define value relevance as the ability of accounting data to capture the basic information of stock prices. Therefore, value relevance as indicated by a statistical association between financial information and prices or returns. Barth et al. (2001) stated that relevance and reliability are the most important quality characteristics of financial statements and combining these two definitions to create a new concept is value relevance. In addition, Barth et al (2001) also pointed out that financial information is considered to be of value relevance if this information has predicted association with the market value of the stock. In line with this argument, Brown (2006) stated that the value relevance of information is the extent to which the accounting profit can summarize information in the market price of stocks. Similarly, Hellström's (2006) argured that the usefulness of financial accounting information in assisting investors in making decisions arising from the relationship between financial statements and stock prices. Nurzi Sebrina and Yuanita Karmenia Sari (2016) argued that one of the signs of value relevance is the investor's reaction to the information provided including: income, book value and information related to dividends are paid. Our study utilized the definition of value relevance of earnings which proposed by Francis và Schipper (1999). The value relevance of accounting earnings is assessed by using the two valuation models proposed by these authors: (a) the magnitude of the adjusted $\mathrm{R}^{2}$ of the Easton and Harris (1991) model; and the magnitude of the adjusted $\mathrm{R}^{2}$ of the Ohlson (1995).

\subsubsection{Accounting conservatism}

Conservatism is the most influential accounting principle in preparing financial statements and also the oldest of these priciples (Sterling, 1970). This principle has effects on accounting practices for centuries (Basu ,1997; Watts, 2013; Yuying Xie, 2015; Yuxiang Zhong, 2016). The degree of accounting conservatism varies from country to country, because it depends on the institutional structure of the economy including the legal system, securities law, tax regime and political economy (Ball et al. 2000; Bushman and Piotroski, 2006). However, there remains considerable confusion over the definition of conservatism and controversial arguments among academic researches (Yuying Xie, 2015). On one hand, conservatism is criticed as a principle that creates difference between book value and market value (Feltham và Ohlson, 1995). On the other hand, some studies suggested that conservatism as a mechanism which rises the value of the firm and benefits for firm's stakeholders (Holthausen and Watts, 2001; Watts, 2003a; Ahmed and Duellman, 2007). Particularly, there are many definitions of accounting conservatism were introduced in academic literature. Bliss (1924) defined conservatism as to foresee all possible losses, but don't expect any uncertain income. That considers as the ealiest definition about conservatism in academic reseaches. Moreover, there are some researchers who made a link between accounting conservatism and the goal of companies along with users of accounting information. This argument was presented in study of Devine (1963). He highlighted that "conservative can be defined in terms of arousing lower average expectations of goal fulfillment than alternative measuring and reporting action". Futhermore, it requires charging an item to expense or loss sooner rather than later with the rule reversed for revenue recognition. Additionally, Watts and Zimmerman (1986) stated that "conservatism means that the accountant should report the lowest value among possible alternative values for assets and the highest alternative value for liabilities. Revenues should be recognized later rather than sooner and expenses sooner than later". However, the impact of accounting conservatism on income statement has not attracted a lot attention until Basu's study (1997). Indeed, Basu interpreted conservatism as a mechanism to capture accoutant's tendency to require higher degree of verification in recognizing good rather bad 
news in earings. Basu performed regression of current net income on stock returns. The measure of convervatism derived from Basu's model illustrated that negative news is recognized faster in earnings than positive news. Thus, he reflected conservatism as earnings reflects bad quickly than good news. Prior literature has developed various measures for accounting conservatism which classified into 4 groups: book-to-market-based measures, accrual-based measures, cash-flow-based measures and Basubased measures. Our study also ulitized widely used Basu-based model to estimate conditional accounting conservatism. According to Basu (1997), $\beta_{3}$ captures the differential recognition speed of bad news in earning respect to good news. This means that the greater the level of conservatism, the greater the asymmetry in the recognition of bad versus good news. Thus, the higher value of $\beta_{3}$, the higher level of conservatism.

$$
X_{i t} / \boldsymbol{P}_{i t-1}=\beta_{0}+\beta_{1} D R_{i t}+\beta_{2} R_{i t}+\beta_{3} D R_{i t} x R_{i t}+\varepsilon_{t}
$$

$\mathrm{X}_{\mathrm{it}}=$ Earning per share firm $\mathrm{i}$ at year $\mathrm{t}$

$\mathrm{P}_{\mathrm{it}-1}=$ Share price firm i year $\mathrm{t}-1$

$\mathrm{R}_{\mathrm{it}}=$ rate of stocks returns firm $\mathrm{i}$ at year $\mathrm{t}:\left(\mathrm{P}_{\mathrm{it}}-\mathrm{P}_{\mathrm{it}-1}+\mathrm{D}_{\mathrm{t}}\right) / \mathrm{P}_{\mathrm{it}-1}$, and $\mathrm{D}_{\mathrm{t}}$ is dividends at year $\quad t$.

$\mathrm{DR}_{\mathrm{it}}$ is a dummy variable that takes the value 1 if $\mathrm{R}_{\mathrm{it}}<0$ and otherwise.

Accounting conservatism is classified into 2 types: conditional and unconditional conservatism based on the capability of reflecting new information about future economic value (Ball and Shivakumar, 2005). This classification is most frequently in the recent literature. Unconditional conservatism is the ex ante understatement of the book value of net assets (Yuying Xie, 2015). Meanwhile, conditional conservatism reflects the differential recognition speed of recognising economic losses compared to recognising gains. Therefore, the notion conservatism in our study refers to conditional conservatism.

\subsubsection{Association between conservatism and value relevance}

Regarding the relationship between conservatism and value relevance, some studies did not use experimental models, however, focused on some particular industrial sections. Lev and Zarowin (1999) found that companies with increased research and development costs (R\&D) higher level of accounting conservatism are significantly suffered from decline in the value relevance of earnings. In addition, Francis and Schipper (1999) concluded that companies operating in the high-tech industries show a strong reduction in the value relevance of earnings compared to the companies of other professions. Besides that, other streams of researches suggest that there is no trade-off between the value relevance and accounting conservatism. For instance, Balachandran and Mohanram (2006) argured that conservatism is unlikely to be the main cause for the declining value relevance of accounting earnings. Similarly, Watt (2003) showed that conservatism in accounting declines potential measurement errors which leads to lack of reliability of accounting information. This results in an increase rather than a decrease of value relevance of earnings.

Balachran and Mohanram (2004) studied the relationship between accounting conservatism and the value relevance of accounting information for companies in the US Compustat Annual Industrial dataset from 1978 to 2002. With the use of four conservatism valuation models of Beaver and Ryan (2000), Penman and Zhang (2002), Lev and Nissim (2004) and Basu (1997), the authors divided the sample into three groups based on measurable accounting conservatism and performed regression of book value on stocks return. The results show that the value relevance only decreases for companies with the lowest level of conservatism and insignificantly varied for companies with the highest conservatism. However, the authors' study did not observe a decrease in the value relevance when utilizing Basu-based model. Similar with this stream of research, Kousenidis et al (2009) conducted a study to assess the impacts reporting conservatism on the value relevance of accounting earnings for Greek companies in the period 1989-2003. Measure of conservatism and value value relevance of accounting earnings are stem from Basu model (1997) and Easton và Harris (1991) respectively. Results illustrate that the level of 
conservatism has increased after the market crisis of 1999 and there is a non-linear relationship between conservative reporting and value relevance of earnings. Specifically, value relevance growths when moving from low-conservative firms to medium-conservative firms and decreases when moving further to high-conservative firms.

Besides that, some studies examine the relationship between accounting conservatism and value relevance in internation context where exists different accounting standards and country-specific factors. For example, Thijssen et al. (2016) investigated this relationship differs under US GAAP and IFRS compliance by using 2 models namely Khan \& Watts (2009) and cash flow model of Ball \& Shivakumar (2005). This paper offered evidence that a rise in timelier loss recognition declines the value relevance of stock prices. Meanwhile, a growth in accrual accounting will increae value relevance. Furthermore, this study also argures that the accounting standard is not a significant predictor for incremental explanatory power considering conservatism and value relevance. Also conducting international research, Brown (2007) studied the relationship between conditional conservatism and value relevance of accounting earnings of 20 countries from 1993-2004 through regression models with OLS least squared estimation method. The model is built with the addition of contry-specific elements including: accrual intensity, legal system (common-law/code-law), tax-book conformity, shareholder protection. The results depict that conditional conservatism is positively associated with the value relevance of earnings higher accrual intensity countries. However, this effect will increase for countries that appear shareholder protection. Similarly selecting international scope of research, Akhloufi (2013) explored the relationship between conditional accounting conservatism and the value relevance of profits at companies in the European Union. Public companies in this region are required to prepare and present financial statements in accordance with international financial reporting standards (IFRS) since 2005. Compliance with IFRS leads to the concept of fair value (fair value) is used more so that the conservative level of accounting decreases. This author concluded that there is an inverse relationship between accounting conservatism and the value relevance of information in Germany after applying IFRS in the preparation and presentation of financial statements.

In Vietnam, there are several researches study the value relevance of financial reporting of listed companies such as Nguyen Viet Dung (2009), Truong Dong Loc and Nguyen Minh Nhat (2016). However, we cannot find any studies that examine the association between accounting conservatism and value relevance of accounting information.

\subsection{Hypothesis development}

Firstly, the accounting system in Vietnam is highly conservatism. This argument could be explained in two aspects includung the legal system and the purpose of the accounting system for businesses in Vietnam. Specifically, Vietnam is a code-law based country so the promulgation and implementation of accounting standards are carried out by state. In addition, the provisions of tax law also affect the measurement and recording accounting data. In particular, the number of businesses in Vietnam is mainly small and medium enterprises with relatively limited access to accounting standards. Therefore, managers mainly use financial statements to determine the tax liability of enterprises for the state budget instead of serving the purpose of monitoring the business operations. In addition, the existence of a unified accounting account system as well as a compliance with the historical cost principle in preparation and presentation of financial statements affect the level of accounting conservatism in Vietnam. Therefore, derived from the above arguments, we formally state the hypothesis as follows:

\section{H1: Conservatism, as measured by Basu-based model is present in the data}

Hypothesis H1 is accepted when the coefficient $\beta 3$ in the model Basu (1997) measures accounting caution with positive and statistically significant conditions.

Secondly, Watts (2003b) claimed that conservatism is mechanism that helps earnings to maintain their relationship with prices by reducing measurement errors in earnings. However, when studying in the context of Vietnam, our study uses the argument of Nguyen Dang Huy (2017) that accounting 
conservatism distorts the value relevance of earnings. Therefore, to explore the relationship between accounting conservatism and the value relevance, the second research hypothesis of the paper states that:

H2: Conservatism helps accounting earnings to exhibit lower information for stock prices.

Hypothesis H2 is accepted when adjusted $\mathrm{R}^{2}$ of models proposed by Ohlson (1995) and Easton \& Harris (1991) is higher for low-level conservatism group (Con1) compared to medium (Con2) and highlevel conservatism groups (Con3).

Lastly, the Vietnamese accounting system is highly conservatism because of two reasons arising from (i) the formulation and promulgation of accounting standards that are only the responsibility of the state, namely the Ministry of Finance and (ii) the large number of small and medium-sized predominantly prepare and present financial statements for the purpose of providing information relating to the determination of payable tax amounts. In addition, the application of the historical cost principle pricing in recording accounting data, the unified accounting system combined with the recognition of economic transactions compliance with tax laws have affected to the quality of financial reporting and accounting conservatism in Vietnam. With shortcomings about the consistency between tax policy and accounting in the legal system as well as the perspective of accountants, circular 200/2014/ TT-BTC dated December 22, 2014 on guiding the accounting regime issued by the Ministry of Finance takes effect from February 5, 2015 and applies to the fiscal year beginning or after January 1, 2015 replaced decision No. 15/2006/QD-BTC and circular No. 244/2009/TT-BTC. Specifically, Circular 200 emphasizes on guiding the recording of book entries accounting, preparation and presentation of financial statements, and does not apply to the determination of corporate tax obligations to the state budget. In stead, it serves the needs of governance, administration and decision making of financial statements' users. This is an innovative point regarding the separation of accounting and taxation highlighted in Circular 200. Therefore, we take the effective time of Circular 200 as a point for dividing the sample into two periods from 2008-2014 and from 2015-2016. With the scope of adjustment clearly stated in the circular emphasizing the purpose of presenting the financial statements inconsistent with the purpose of tax obligations, we expect that level of caution in accounting period 2015-2016 will be lower than the period 2008-2014. Therefore, the third research hypothesis states that:

H3: The level of conservatism is higher for the period of 2008-2014 than for the period of 20152016.

To examine the validity of the above research hypothesis, we split sample into two sub-periods and measure conservatism separately for each period. If a slope coefficient $\beta_{3}$ for the sub-period 2008-2014 is higher than that in 2015-2016. Then, research hypothesis H3 cannot be rejected.

\section{RESEARCH METHOLOGY}

\subsection{Data}

The research sample does not include financial, banking, insurance and securities companies as the regulations related to the preparation and presentation of financial statements are not identical with the remaining companies of the research sample. In addition, companies are selected to collect data with an accounting period from January 1 to December 31 in the fiscal year and they do not change the accounting period during the study period. After eliminating companies in the finance, banking, insurance and securities industries, the remaining sample includes 521 companies for the period 2008-2016. After that, authors remove companies with insufficient data to calculate the independent variables and dependent variables in the accounting conservatism model value relevance as well as invalidated continuously data for 9 years from 2008-2016. According to Givoly, Hayn and Natarayan (2006), to ensure the strength of Basu's conditional accounting model of prudent accounting (1997), each selected company must have at least sufficient data to calculate for 5 years. Therefore, in order to ensure this requirement as well as to facilitate the calculation, the author has selected companies with sufficient computational data within 9 years. Finally, data used in our research including audited financial 
statements data and market data of 97 companies listed on the HOSE and HNX in the period of 20082016 with 873 observations.

\subsection{Research model and variables measurement}

\subsubsection{Value relevance models}

In order to estimate value relevance, this paper uses the model of Ohlson (1995)

$$
\boldsymbol{P}_{i t}=\beta_{0}+\beta_{1} B V_{i t}+\beta_{2} E P S_{i t}+\varepsilon_{i t}
$$

And the return-equivalent of Easton \& Harris (1991)

$$
\boldsymbol{R e t}_{i t}=\boldsymbol{\beta}_{0}+\boldsymbol{\beta}_{1} \frac{E P S_{i t}}{\boldsymbol{P}_{i, t-1}}+\boldsymbol{\beta}_{2} \frac{\Delta E P}{\boldsymbol{P}_{i, t-1}}+\varepsilon_{i t}
$$

Our research uses the views of Francis and Schipper (1999), Barth et al. (2001), Brown (2006), Hellström (2006) on the value relevance of information. In this case, the ability of accounting data is to summary basic information of stock prices. Therefore, to measure the value relevance of accounting information, most scholars when developing the measurement model are based on the R2 correction factor. In the two above models, the R2 indicate that accounting data explains how much of the variation in stock prices or returns per share ratio and the higher R2, the higher level of value relevance for accounting information.

\begin{tabular}{|c|c|c|c|}
\hline Variables & Code & Note & Model \\
\hline Stock price & $\mathrm{P}_{\mathrm{it}}$ & $\begin{array}{l}\text { The share price of firm } \mathrm{i} \text { at year } \mathrm{t} \text { on } \\
\text { March } 31 \text {. }\end{array}$ & Ohlson (1995) \\
\hline Book value & $\overline{B V_{\text {it }}}$ & $\begin{array}{l}\text { The per share book value of equity } \\
\text { of firm } i \text { at year } t\end{array}$ & Ohlson (1995) \\
\hline Earning per share & $\mathrm{EPS}_{\text {it }}$ & $\begin{array}{l}\text { The earnings per share of firm } i \text { at } \\
\text { year } t\end{array}$ & Ohlson (1995) \\
\hline Return - equivalent & $\operatorname{Ret}_{\text {it }}$ & $\begin{array}{l}\text { (Stock price of firm } i \text { at year } t+ \\
\text { dividend at year } t-\text { Stock price of } \\
\text { firm } i \text { at year } t-1 \text { ) Stock price of } \\
\text { firm } i \text { at year } t-1 \text { ) }\end{array}$ & $\begin{array}{l}\text { Easton \& Harris } \\
\text { (1991) }\end{array}$ \\
\hline $\begin{array}{l}\text { Difference of earnings } \\
\text { per share }\end{array}$ & $\triangle \mathrm{EPS}_{\text {it }}$ & $\begin{array}{l}\text { Earnings per share firm } i \text { at year } t- \\
\text { Earnings per share firm } i \text { at year } t-1\end{array}$ & $\begin{array}{l}\text { Easton \& Harris } \\
\text { (1991) }\end{array}$ \\
\hline $\begin{array}{l}\text { Stock price of the } \\
\text { previous year }\end{array}$ & $\mathrm{P}_{\mathrm{it}-1}$ & $\begin{array}{l}\text { The stock price of firm } i \text { at } \\
\text { December } 31 \text { in year t- } 1 \text {. }\end{array}$ & $\begin{array}{l}\text { Easton \& Harris } \\
\text { (1991) }\end{array}$ \\
\hline
\end{tabular}

Table 1. Measurement of variables in value relevance models

\subsubsection{Conditional accounting conservatism model}

In order to estimate conditional accounting conservatism by each company, the author uses Basu model (1997) through partial linear regression technique:

$$
X_{i t} / \boldsymbol{P}_{i t-1}=\beta_{0}+\beta_{1} D R_{i t}+\beta_{2} R_{i t}+\beta_{3} D R_{i t} x R_{i t}+\varepsilon_{t}
$$

Accounting conservatism is measured through regression coefficients $\beta 3$ with Basu's model (1997). Therefore, if these regression coefficients are positive $(+)$, information in the financial statements is and meaningful and made on the prudent principle. The higher posotive coefficient $\beta 3$, the higher level of accounting conservatism.

In addition, while considering the impact of conditional accounting conservatism on the value relevance of financial information, the research sample is divided into three groups including the high level, average level or low level of accounting conservatism after calculating for each company in 9 year from 2008 to 2016 so the Basu model (1997) was selected as appropriate for this research. 
Table 2. Measurement of variables in accounting conservatism model

\begin{tabular}{|l|c|l|c|}
\hline \multicolumn{1}{|c|}{ Variables } & Code & \multicolumn{1}{|c|}{ Note } & Model \\
\hline Earning per share & $\mathrm{X}_{\mathrm{it}}$ & Earnings per share firm $\mathrm{i}$ at year $\mathrm{t}$ & Basu (1997) \\
\hline $\begin{array}{l}\text { Stock price of the } \\
\text { previous year }\end{array}$ & $\mathrm{P}_{\mathrm{it}-1}$ & $\begin{array}{l}\text { The stock price of firm i at December } \\
31 \text { in year } \mathrm{t}-1 .\end{array}$ & Basu (1997) \\
\hline $\begin{array}{l}\text { The annually } \\
\text { compounded stock } \\
\text { returns of firm i at } \\
\text { year } \mathrm{t}\end{array}$ & $\mathrm{R}_{\mathrm{it}}$ & $\begin{array}{l}\text { (Stock price of firm } \mathrm{i} \text { at year } \mathrm{t}+ \\
\text { dividend at year } \mathrm{t}-\text { Stock price of firm i } \\
\text { at year } \mathrm{t}-1) / \text { Stock price of firm } \mathrm{i} \text { at year } \\
\mathrm{t}-1)\end{array}$ & Basu (1997) \\
\hline Dummy & & $\mathrm{DR}_{\mathrm{t}}=1$ if $\mathrm{R}_{\mathrm{it}}<0, \mathrm{DR}_{\mathrm{it}}=0$ if $\mathrm{R}_{\mathrm{it}}>0$ & Basu (1997) \\
\hline
\end{tabular}

\subsection{Research design}

To test the hypotheses set out in this study, authors perform data panel regression step by step as following:

- Measuring the degree of accounting conservatism by pooled OLS regression model (on three particular periods: 2008-2016, 2008-2014 and 2015-2016)

- Measuring the conditional accounting conservatism level of each company in the research sample to divide them into three groups based on three estimated levels. According to Balachandran and Mohanram (2004), Kousenidis et al. (2009), the sample is divided into three groups with low, medium and high level. In particular, the company has a low level of conservative accounting with $30 \%$ of the sample companies with the lowest caution and named Con1. In contrast, the company has a high level of prudent accounting accounting for 30\% of the companies with the highest conservatism and named Con3. The remaining $40 \%$ of the companies in the sample will be classified as having a medium level of accountability and named Con2. Then, we determine the level of conditional accounting conservatism of three groups Con1, Con2 and Con3 on the three periods 2008-2016, 2008-2014 and 2015-2016.

- Measuring the value relevance of accounting information according to the combined regression model (Pooled OLS) in three periods: 2008-2016, 2008-2014 and 2015-2016.

- Measuring the value relevance of accounting information of three groups Con1, Con2 and Con 3 on the three periods 2008-2016, 2008-2014 and 2015-2016 in order to make comments about the impact of conditional accounting conservatism on the value relevance of accounting information.

\section{RESULTS AND DISCUSSION}

\subsection{Descriptive statistics}

Table 3. Descriptive statistics

\begin{tabular}{r|rrrrr} 
Variable & Obs & Mean & Std. Dev. & Min & Max \\
\hline epsdivpt_1 & 873 & .329222 & .456981 & -.7060127 & 1.127154 \\
rit & 873 & .3370013 & .8618454 & -.9391139 & 2.354022 \\
dr & 873 & .6242841 & .4845848 & 0 & 1 \\
ret & 873 & .3370013 & .8618454 & -.9391139 & 2.354022 \\
deltaepsdi 1 & 873 & .1440884 & .2994408 & -.4020088 & .965291 \\
\hline p & 873 & 89051.89 & 38718.73 & 1300 & 156800 \\
bv & 873 & 47069.16 & 12478.26 & 22778 & 76763 \\
eps & 873 & 10136.89 & 3813.671 & -1872.83 & 17293.64
\end{tabular}


The table 3. illustrates the descriptive statistics of each variables including mean, standard deviation, minimum and maximum value in all models used and the estimated value of conservatism.

\subsection{Regression results}

\subsubsection{Results of the Basu Model to mesure conditional accounting conservatism}

To estimate conditional accounting conservatism, this paper uses the model proposed by Basu (1997). The results of the pooled OLS regression model with conditional accounting conservatism are used to test the hypothesis $\mathrm{H} 1$ and the hypothesis $\mathrm{H} 3$.

Table 4. Results of pooled OLS model to mesure conditional accounting conservatism

\begin{tabular}{|l|c|r|r|r|r|r|r|r|}
\hline & \multicolumn{1}{|c|}{$\boldsymbol{\beta}_{\mathbf{0}}$} & $\mathbf{p}$-value & \multicolumn{1}{|c|}{$\boldsymbol{\beta}_{\mathbf{1}}$} & \multicolumn{1}{c|}{$\mathbf{p}$-value } & \multicolumn{1}{c|}{$\boldsymbol{\beta}_{\mathbf{2}}$} & \multicolumn{1}{c|}{$\mathbf{p}$-value } & \multicolumn{1}{c|}{$\boldsymbol{\beta}_{\mathbf{3}}$} & $\mathbf{p}$-value \\
\hline $2008-2016$ & 0.5435 & 0.000 & -0.0242 & 0.6180 & 0.1095 & 0.0940 & $\mathbf{0 . 6 0 9 3}$ & $\mathbf{0 . 0 0 0 0}$ \\
\hline $2008-2014$ & 0.5472 & 0.000 & -0.0352 & 0.5140 & 0.0956 & 0.1930 & $\mathbf{0 . 6 2 0 5}$ & $\mathbf{0 . 0 0 0 0}$ \\
\hline $2015-2016$ & 0.5300 & 0.000 & 0.0176 & 0.8760 & 0.1545 & 0.2900 & $\mathbf{0 . 5 7 8 8}$ & $\mathbf{0 . 0 0 2 0}$ \\
\hline Con1 & 0.6593 & 0.000 & -0.2951 & 0.0010 & -0.0559 & 0.6380 & $\mathbf{0 . 6 0 1 5}$ & $\mathbf{0 . 0 0 0 0}$ \\
\hline $2008-2014$ & 0.6713 & 0.000 & -0.3334 & 0.0000 & -0.0904 & 0.4960 & 0.6197 & 0.0000 \\
\hline $2015-2016$ & 0.6031 & 0.003 & -0.1058 & 0.6610 & 0.0580 & 0.8470 & 0.6125 & 0.1010 \\
\hline Con2 & 0.5049 & 0.000 & 0.1042 & 0.2110 & 0.1745 & 0.1620 & $\mathbf{0 . 6 5 3 5}$ & $\mathbf{0 . 0 0 0 0}$ \\
\hline $2008-2014$ & 0.4979 & 0.000 & 0.1056 & 0.2570 & 0.1534 & 0.2540 & 0.6881 & 0.0000 \\
\hline $2015-2016$ & 0.4941 & 0.007 & 0.1229 & 0.6200 & 0.3487 & 0.3230 & 0.4060 & 0.3010 \\
\hline Con3 & 0.6948 & 0.000 & -0.0590 & 0.4480 & -0.1577 & 0.0920 & $\mathbf{1 . 1 8 9 8}$ & $\mathbf{0 . 0 0 0 0}$ \\
\hline $2008-2014$ & 0.7255 & 0.000 & -0.0621 & 0.4720 & -0.1957 & 0.0680 & 1.2616 & 0.0000 \\
\hline $2015-2016$ & 0.5933 & 0.000 & -0.1069 & 0.5660 & -0.0328 & 0.8670 & 0.8755 & 0.0040 \\
\hline
\end{tabular}

Table 4. shows the results of the regression model including conditional accounting conservatism value in terms of 3 periods 2008-2016, 2008-2014, 2015-2016 as well as 3 groups Con1, Con2 and Con3 classified. Based on the results provided, it is clear that the coefficient $\beta 3$ of Basu model (1997) all stages and groups are positive and statistically significant with the co of 5\% (except for low level group and medium level group in the period 2015-2016). Specifically, the value of $\beta 3$ measure of conservative accounting for the period 2008-2016 is 0.6093 with p-value of 0.0000 . Thus, it can be concluded that conditional accounting conservatism is measured by the slope coefficient $\beta 1$ in the Basu model (1997) existing in the research data or hypothesis $\mathrm{H} 1$ is accepted at the $5 \%$ significance level.

At the time of separation point (the year of 2015), the results illustrate that conditional accounting conservatism of the period 2008-2014 is 0.6205 with p-value of 0.0000. Similarly, the period 2015-2016 has a conditional accounting caution of 0.5788 with p-value of 0.0020 . In consequence, it can be seen that the value of slope coefficient $\beta 3$ in Basu model (1997) in the period of 2008-2014 is higher and statistically higher than those of the period of 2015-2016. In other words, conditional accounting conservatism level for the period 2008-2014 are higher than in 2015-2016 and hypothesis H3 is accepted.

The results of prudent accounting studies with respect to listed companies in Vietnam stock market are similar to those of Kousenidis et al (2009) in Greece. An interesting point is that Greece and Vietnam 
are code-law based contries, so the research results show that the accounting system of the two countries is more conservatism.

Our research select the time of 2015 to consider the conditional accounting caution of the previous study and after this time when the Circular 200/2014 / TT-BTC issued with the emphasis on the purpose of separating the effective accounting and tax. The results show that the conditional accounting conservatism value of the period 2008- 2014 is higher than that of the period of 2015-2016. This implies that the separation of the purpose between accounting and tax has made the conservatism of the information presented in the financial statements decrease. This result is in line with the outlook of Circular 200 when it aims to serve the needs of governance, administration and decision making of stakeholders.

\subsubsection{The pooled OLS regression model to measure value relevance and impact of conditional accounting conservatism on value relevance}

In order to estimate value relevance of accounting information and the effect of acconting conservatism on value relevance, two pooled OLS regressions model proposed by Easton \& Harris (1991) and Ohlson (1995) are used in this paper.

\section{a. Results of regressions using the Easton and Harris model (1991)}

Table 5. Results of the Easton and Harris Model

\begin{tabular}{|l|r|r|r|r|r|r|r|}
\hline Period & \multicolumn{1}{|c|}{$\boldsymbol{\beta}_{\mathbf{0}}$} & \multicolumn{1}{c|}{$\mathbf{p}$-value } & \multicolumn{1}{c|}{$\boldsymbol{\beta}_{\mathbf{1}}$} & \multicolumn{1}{c|}{$\mathbf{p}$-value } & \multicolumn{1}{c|}{$\boldsymbol{\beta}_{\mathbf{2}}$} & \multicolumn{1}{c|}{$\mathbf{p}$-value } & $\begin{array}{c}\text { Adjusted } \\
\mathbf{R}^{\mathbf{2}}\end{array}$ \\
\hline $2008-2016$ & -0.0718 & 0.0610 & 1.0124 & 0.0000 & 0.5242 & 0.0000 & $23.78 \%$ \\
\hline $2008-2014$ & -0.0687 & 0.1140 & 1.0187 & 0.0000 & 0.5244 & 0.0000 & $23.87 \%$ \\
\hline $2015-2016$ & -0.0832 & 0.3120 & 0.9926 & 0.0000 & 0.5233 & 0.0100 & $22.71 \%$ \\
\hline Con1 & 0.0896 & 0.2110 & 0.8073 & 0.0000 & 0.2862 & 0.0800 & $\mathbf{1 4 . 2 3 \%}$ \\
\hline $2008-2014$ & 0.1534 & 0.0790 & 0.7555 & 0.0000 & 0.2100 & 0.2520 & $10.75 \%$ \\
\hline $2015-2016$ & -0.0855 & 0.4970 & 0.8895 & 0.0000 & 0.5448 & 0.1700 & $24.60 \%$ \\
\hline Con2 & -0.0693 & 0.2460 & 1.0796 & 0.0000 & 0.3916 & 0.0070 & $\mathbf{2 8 . 0 0 \%}$ \\
\hline $2008-2014$ & -0.0984 & 0.1360 & 1.0662 & 0.0000 & 0.4523 & 0.0070 & $28.21 \%$ \\
\hline Con3 & 0.0299 & 0.8360 & 1.0968 & 0.0000 & 0.2318 & 0.4340 & $24.58 \%$ \\
\hline $2008-2014$ & -0.2254 & 0.0010 & 1.1206 & 0.0000 & 1.0054 & 0.0000 & $\mathbf{2 8 . 3 2 \%}$ \\
\hline $2015-2016$ & -0.2165 & 0.0060 & 1.1622 & 0.0000 & 0.9971 & 0.0000 & $30.75 \%$ \\
\hline
\end{tabular}

The table 5. tabulates the results of the Easton and Harris Model (1991). These results show that the value relevance of accounting information for the period of 2008-2016 is $23.78 \%$ and for the period 20082014 and $2015-2016$ are $23.87 \%$ and $22.71 \%$ respectively. The period before 2015 has an appropriate value of accounting information higher than the period after 2015, but the difference between these two periods is not significant with only $1.16 \%$.

Specifically, the value relevance of information measured by the adjusted coefficient of R2 on three classified groups Con1, Con 2 and Con 3 are $14.23 \%, 28.00 \%$ and $28.32 \%$, respectively. Thus, when the 
level of conservatism increases gradually from low level to high level, this tendency make the value relevance of information increase. This is clearly can be seen when we focus on groups in the period from 2008 to 2014.

Therefore, the hypothesis $\mathrm{H} 2$ was rejected when the adjusted coefficient R2 of the model Easton \& Harris (1991) and the slope were higher for companies with high levels of conservatism (Con3) compared to the group with low level (Con1) and medium (Con2). However, the value relevance estimation between Con 2 and Con 3 groups does not have a significant difference $(0.32 \%)$. This conclusion contrasts with the results that Lev and Zarowin (1999) and Akhloufi (2013). However, in the period after Circular 200/2014 / TT-BTC (from 2015 to 2016), the results implies that the higher the level of accounting conservatism has distorted or caused the reduction of value relevance.

In addition, the earnings variable has a high explanation for the dependent variable in the model earning per shaer. This is reflected in the slope coefficient $\boldsymbol{\beta 1}$ in the model of Easton \& Harris (1991), which are statistically significant at the level of 5\%. And this tend is similary to all periods and groups researched. However, the difference of earnings per share share divided by the price of a stock in $\mathrm{t}-1$ year is not possible to explain the dependent variable in the model. Specifically, the slope of $\beta 2$ of the group with the lowest degree of conservatism in all levels is not statistically significant at the $5 \%$ significance level. The same is true for the mid-conservatism portfolio conditional accounting caution in the period 2015-2016.

\section{b. Results of regressions using the Ohlson model (1995)}

Table 6. Results of regressions using the Ohlson model (1995)

\begin{tabular}{|l|c|r|r|r|r|r|r|}
\hline Period & $\boldsymbol{\beta 0}$ & $\boldsymbol{p}$-value & $\boldsymbol{\beta 1}$ & \multicolumn{1}{c|}{ p-value } & $\boldsymbol{\beta} 2$ & p-value & $\begin{array}{c}\text { Adjusted } \\
\text { R2 }\end{array}$ \\
\hline $2008-2016$ & 184904.5000 & 0.0000 & -1.5053 & 0.0000 & -2.4662 & 0.0000 & $37.07 \%$ \\
\hline $2008-2014$ & 184246.8000 & 0.0000 & -1.4910 & 0.0000 & -2.4853 & 0.0000 & $36.75 \%$ \\
\hline $2015-2016$ & 187122.8000 & 0.0000 & -1.5528 & 0.0000 & -2.4008 & 0.0000 & $37.53 \%$ \\
\hline Con1 & 170047.0000 & 0.0000 & -1.2956 & 0.0000 & -1.9025 & 0.0000 & $\mathbf{2 6 . 7 4 \%}$ \\
\hline $2008-2014$ & 159835.1000 & 0.0000 & -0.9872 & 0.0000 & -2.3202 & 0.0020 & $24.64 \%$ \\
\hline $2015-2016$ & 203588.5000 & 0.0000 & -2.0598 & 0.0000 & -1.4769 & 0.1840 & $37.05 \%$ \\
\hline Con2 & 182114.9000 & 0.0000 & -1.4928 & 0.0000 & -2.3531 & 0.0000 & $\mathbf{3 1 . 1 0 \%}$ \\
\hline $2008-2014$ & 182933.1000 & 0.0000 & -1.6100 & 0.0000 & -1.9431 & 0.0010 & $31.84 \%$ \\
\hline $2015-2016$ & 177530.1000 & 0.0000 & -0.9642 & 0.0020 & -4.0422 & 0.0000 & $29.90 \%$ \\
\hline Con3 & 197521.7000 & 0.0000 & -1.6186 & 0.0000 & -3.0969 & 0.0000 & $\mathbf{5 2 . 2 3 \%}$ \\
\hline $2008-2014$ & 200052.3000 & 0.0000 & -1.5799 & 0.0000 & -3.4981 & 0.0000 & $52.78 \%$ \\
\hline $2015-2016$ & 190615.2000 & 0.0000 & -1.8007 & 0.0000 & -1.6740 & 0.1320 & $49.96 \%$ \\
\hline
\end{tabular}

The results indicate that the value relevance of accounting information for the period of 2008-2016 is $37.07 \%$ and for the $2008-2014$ and $2015-2016$ periods are $36.75 \%$ and $37.53 \%$ respectively. Therefore, each company's stock return and book value explain $37.07 \%, 36.75 \%, 37.53 \%$ of stock price fluctuation in three months after the end of the fiscal year. It can be seen that the value relevance of information 
measured by Ohlson model (1995) gives higher results than of the model developed by Easton \& Harris (1991). In addition, the period before 2015 has appropriate value of accounting information lower than the period after 2015 , but the difference between these two periods is not significant with $0.78 \%$. This result contrasts with the the measurement of Easton \& Harris (1991) model.

Specifically, the value relevance measured with adjustment factor R2 of Ohlson model (1995) on three groups Con 1 , Con 2 and Con 3 is $26.74 \%, 31.10 \%$ and $52.23 \%$, respectively. Therefore, the higher conservatism level, the higher value relevance of earnings. This tendency can be seen clearly when considering the variation in the value relevance of information for groups during 2008-2014. This result is similar to the conclusion drawn after the pooled OLS regression model of Easton \& Harris (1991). Therefore, the hypothesis $\mathrm{H} 2$ was rejected.

Regarding the consideration of the effect of conditional accounting conservatism on the value relevance of information on financial statements, both models by Easton \& Harris (1991) and Ohlson (1995) all produce the same results. Specifically, the higher the level of accounting conservatism, the higher value relevance of information. This result shows a positive relationship between the effect of conditional accounting caution on the appropriate value of information. This conclusion is inconsistent with Balachndran and Mohanram (2004), Kousenidis and colleagues (2009), Balachndran and Mohanram (2011), Akhloufi (2013) and inline with Thijssen et al (2016) when the these authors use cash flow-based models to measure accounting conservatism.

\section{CONCLUSION}

According to the interpretation of Basu's model (1997), the author concludes that conservatism is a salient feature of the Vietnamese accounting system, and this finding is appropriate with the code-law based accounting regimes.

By using two pooled OLS regressions proposed by Ohlson (1995) and Easton and Harris (1991), this paper identifies the positive association between accounting conservatism and value relevance of information from financial statement Vietnamese listed companies.

Although the level of conditional conservatism in the period of 2008-2014 is higher than that of the period 2015-2016, we cannot find any evidence for greater value relevance of earnings for period before 2015 when considering both models of Easton \& Harris (1991) and Ohlson (1995).

\section{LIMITATIONS AND SUGGESTIONS FOR FUTURE RESEARCH}

Firstly, about the time of research, we collect data of listed companies on Vietnam stock market in the period of 9 years from 2008-2016. However, for previous studies, the study period was usually collected over a long period of 15 years according to the study of Kousenidis et al. (2009) or 30 years as in the study of Balachndran \& Mohanram (2011). Therefore, long period research helps to increase the consistency of measurement models as well as conclusions about the effects of accounting conservatism on value relevance. Secondly, in terms of research methods, accounting conservatism and value relevance are measured on different stages, different groups so we only use pooled regression models combined to test the hypotheses. Thirdly, this research only studies the effect of conditional accounting conservatism on the value relevance of listed companies' earnings. This conclusion does not provide evidence for nonlisted companies on the Vietnamese stock market and association between value relevance on earnings and unconditional conservatism.

With the above limitations of the topic, we have some suggestions for future research directions. In the study of Kousenidis et al. (2009), the authors used the estimation of Pooled Common Correlated Effects (CCE) of Pesaran (2006) to control two problems arising in panel data with large observations in the short period are cross-dependent and variance changes. Therefore, in further study, we can apply this estimation technique to understand the effect of accounting conservatism on value relevance of earnings and then compare with the results obtained from pooled OLS regression. Moreover, we can conduct a 
research related to the effect of unconditional accounting conservatism on the value relevance of earnings of listed companies on the Vietnamese stock market and compare conditional conservatism.

\section{REFERENCE}

[1] Bộ Tài chính, 2014. Thông tư số 200/2014/TT-BTC ngày 22/12/2014 Về hướng dẫn chế độ kế toán doanh nghiệp.

[2] Nguyễn Việt Dũng, 2009. Mối liên hệ giữa thông tin báo cáo tài chính và giá cổ phiếu: Vận dụng linh hoạt lý thuyết hiện đại vào trường hợp Việt Nam. Tạp chí nghiên cứu kinh tế, 375, 18-32.

[3] Trương Đông Lộc và Nguyễn Minh Nhật, 2016. Ảnh hưởng của thông tin kế toán đến giá của các cổ phiếu: Bằng chứng thực nghiệm từ Sở giao dịch chứng khoán TP. Hồ Chí Minh. Tạp chí khoa học Đại học Mở TP.HCM, số 4(49), trang 62-71.

[4] Võ Văn Nhị và Lê Hoàng Phúc, 2011. Sự hoà hợp giữa chuẩn mực kế toán Việt Nam và chuẩn mực kế toán quốc tế - Thực trạng, nguyên nhân và định hướng phát triển. Tạp chi Kiểm toán, số 12, trang 29-36.

[5] Ahmed, A.S and Duellman, S., 2007. Accounting conservatism and Board of director characteristics: an empirical analysis. Journal of Accounting and Economics, 43 (2-3): 411-437.

[6] Akhloufi, F., 2013. The relationship between conditional conservatism and value relevance of earnings. Master thesis. Erasmus School of Economics.

[7] Balachandran, S. and Mohanram, P., 2004. Conservatism and the value relevance of financial information. Working Paper, Columbia University

[8] Balachandran, S., Mohanram, P., 2011. Is the decline in the value relevance of accounting driven by increased conservatism? Rev. Account. Stud, 16 (2):272-301

[9] Ball, R., and L. Shivakumar, 2005. Earnings quality in U.K. private firms. Journal of Accounting \& Economics, 39(1): 83-128.

[10] Ball, R., Kothari, S.P. and Robin, A. (2000) 'The effect of international institutional factors on properties of accounting earnings', Journal of Accounting and Economics, Vol. 29, pp.1-51.

[11] Basu, S., 1997. The conservatism principle and the asymmetric timeliness of earnings. Journal of Accounting \& Economics, 24: 3-27.

[12] Bliss, J.H., 1924. Management Through Accounts, The Ronald Press Co., New York

[13] Brown Jr., W.D., He, H., Teitel, K., et al., 2006. Conditional conservatism and the value relevance of accounting earnings: an international study. Eur Account. Rev,15 (4):605-626

[14] Bushman, R.M. and Piotroski, J. (2006) 'Financial reporting incentives for conservative accounting: the influence of legal and political institutions', Journal of Accounting and Economics, Vol. 42, pp.107-148

[15] Devine, C.T.,1963. The Rule of Conservatism Reexamined. Journal of Accounting Research, 1: 12738 
[16] Dimitrios V. Kousenidis, Anestis C. Ladas, Christos I. Negakis, 2009. Value relevance of conservative and non-conservative accounting information. The International Journal of Accounting, 44:219-238

[17] Feltham, G., and J. Ohlson. "Valuation and clean surplus accounting for operating and financial activities. Contemporary Accounting Research, 11(2): 689-731.

[18] Francis, J. and Schipper, K. ,1999. Have financial statements lost their relevance, Journal of Accounting Research, 37(2): 319-352.

[19] Givoly, D., and C. Hayn, 2000. The changing time series properties of earnings, cash flows, and accruals: Has financial reporting become more conservative? Journal of Accounting \& Economics, 29: $287-320$.

[20] Holthausen, R.W and Watts, R.L, 2001. The relevance of the value relevance literature for financial accounting standard setting. Journal of Accounting and Economics, 31 (1-3): 3-75.

[21] Khan, M., and R. L. Watts, 2009. Estimation and empirical properties of a firm-year measure of accountingconservatism. Journal of Accounting \& Economics, 48: 132-150.

[22] Maximiliaan Willem Pierre Thijssen, George Emmanuel Iatridis, 2016. Conditional conservatism and value relevance of financial reporting: A study in review of converging accounting standards. Journal of Multinaltional Financial Management, 37-38:48-70

[23] Watts, R. L., 2003a. Conservatism in accounting, Part I: Explanations and implications. Accounting Horizons, 17 (3): 207-221.

[24] Watts, R. L., 2003b. Conservatism in accounting, Part II: Evidence and research opportunities. Accounting Horizons, 17 (4): 287-301.

[25] Watts, R.L and Zimmerman, J.L, 1986. Positive Accounting Theory. Prentice-Hall, Toronto.

[26] Yuxing Zhong, 2016. Accounting conservatism: A literature review. Australian accounting review, 27(2):195-213.

[27] Yuying Xie, 2015. Confusion over accounting conservatism: A critical review. Australian accounting review, 25(2):204-216.

[28] Zhang, X.J., 2000. Conservatism accounting and equity valuation. Journal of Accounting and Economics, 29(1): 125-149.

Received on February 1st, 2019

Accepted on March 25th, 2019 